\title{
The Influence of Brand Images, Social Media Marketing, Prices and Reference Groups Towards Buying Decision In Swiwings Narotama Outlet Surabaya
}

\author{
Septia Wahyu Monica ${ }^{\mathrm{a},{ }^{*},}$, Santirianingrum Soebandhi ${ }^{\mathrm{b}}$, Ani Wulandari ${ }^{\mathrm{c}}$ \\ ${ }^{a}$ Faculty of Economics and Business, Narotama University, Jl Arief Rachman Hakim 51, Sukolilo, Surabaya, Indonesia \\ ${ }^{b}$ Faculty of Economics and Business, Narotama University, Jl Arief Rachman Hakim 51, Sukolilo, Surabaya, Indonesia \\ ${ }^{c}$ Faculty of Economics and Business, Narotama University, Jl Arief Rachman Hakim 51, Sukolilo, Surabaya, Indonesia
}

\begin{abstract}
This study aims to examine the influence of Brand Image, Social Media Marketing, Price And Reference Groups towards Purchasing Decision in Swiwings Narotama Outlet. Data collection techniques used was questionnaire with the analysis technique of multiple linear regression. The study found that Brand Image, Price have no significant effect towards Purchasing Decision, meanwhile Social Media and Reference Group have a significant effect towards buying decisions at Swiwings Narotama Outlet in Surabaya. Simultaneously, Brand Image, Social Media Marketing, Price and Group References have a significant effect towards Buying Decisions in Swiwings Narotama Outlet.
\end{abstract}

Keywords: Brand Images, Social Media Marketing, Prices, Reference Groups.

\section{Introduction}

The development of business today is starting to develop very rapidly. With this marked by various types of businesses that have just emerged. Therefore it needs to be balanced with sufficient and adequate food availability. Food which is a basic human need. Changing conditions and the environment require people to always follow the tastes of consumers and the times. At present the business in the service sector is a business that is in demand by marketers. One of them is a service industry business that is engaged in the culinary field.

The current phenomenon that is one of the most popular social media and is one of the excellent features on smartphones is Instagram. Instagram is a photo sharing application, applies digital filters and shares them to various social media networking services, including Instagram's own). The social media system on Instagram is by being a follower of another user's account or having followers of an Instagram account can also be called (followers \& following). Communication between Instagram users can be established by giving likes and commenting on photos that have been uploaded by other users.

That is the result of a study of a total of 56 million users or 20.97 percent of the total Instagram user population in Indonesia. The study also revealed that in early 2019 the average number of male Instagram users was 1.9 percent more than women.

The phenomenon of this research is the brand image of Swiwings is not too well known by the public, but Swiwings is trying to build a brand image so that consumers are interested in buying Swiwings products. In this case Swiwings seeks to maintain its brand image by conducting promotions through Social Media Marketing such as Instagram.

\footnotetext{
* Corresponding author.

E-mail address: sepiawahyumonica@gmail.com (Septia Wahyu Monica)
} 


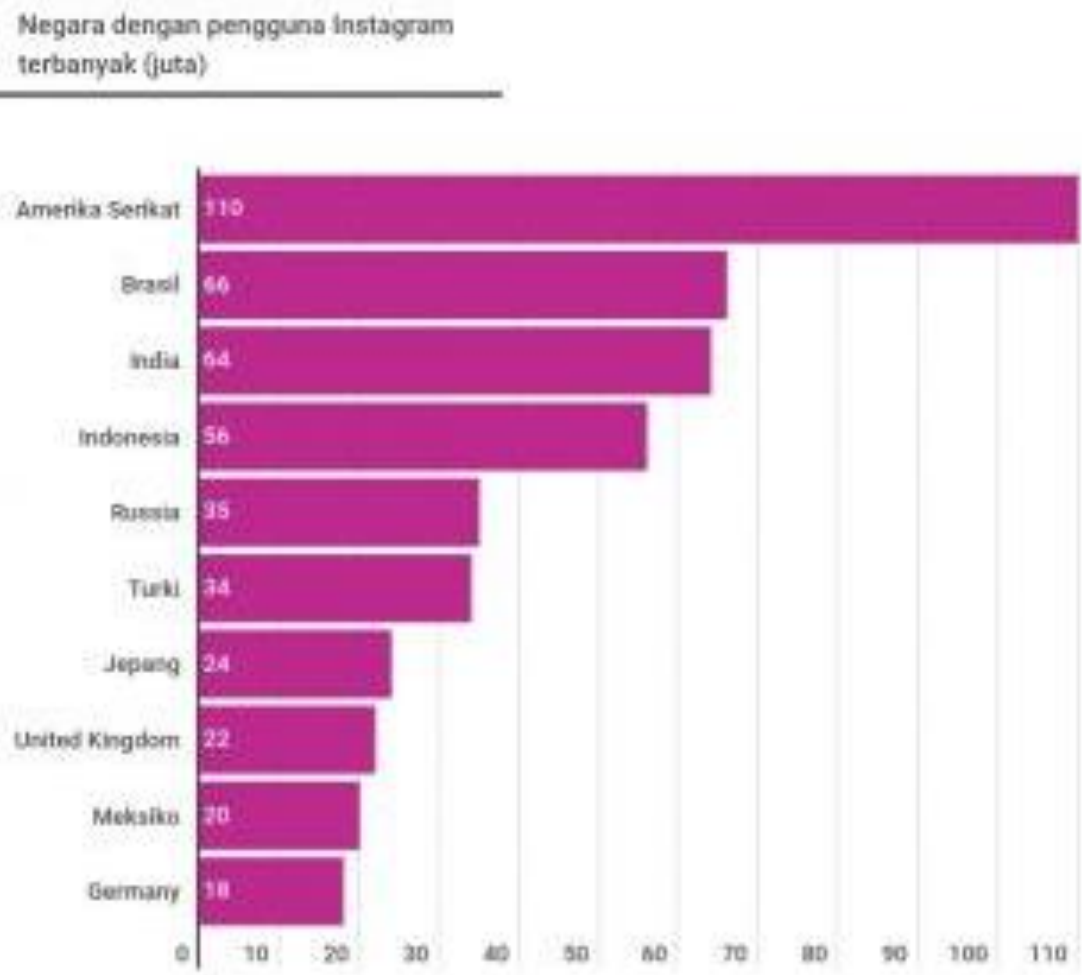

Fig. 1. The Instagram user survey results

Source: (Pratnyawan, 2019)

Swiwings Chicken is a culinary company, which was established on February 1, 2017, which is made from chicken wings with additional choices of sauces made by Swiwings Company, such as Hotblazt Sauce, Cheese Sauce, Teriyaki Sauce, Barbeque Sauce. With this variety of foods with taste makes consumers more interested and decides to buy. Promotion strategies used by Swiwings companies use Instagram marketing as a means to carry out their marketing activities. The Instagram Account Swiwings (fig. 2).

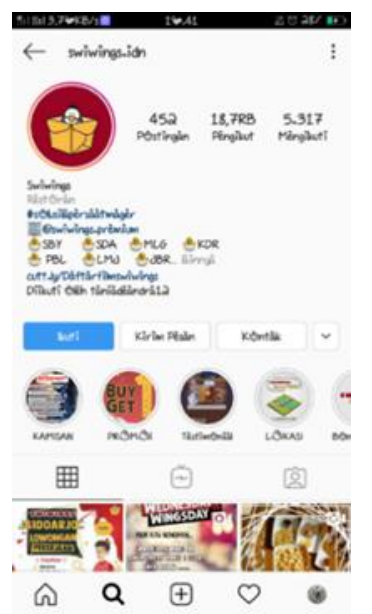

Fig. 2 Swiwings primary data

Source : https://instagram.com/swiwings.idn?igshid=13dj5smihcmk6 
Can be seen from the picture above, Instagram Account Swiwings Idn has followers as many as 18.7 thousand people spread almost all over Indonesia.

In this case, Instagram can provide convenience for the Swiwings Narotama Outlet to market its products to touch the public more. Consumers are generally aware of the promotion of beverage products and food sold by Narotama Swiwings Outlet through information provided on Instagram Accounts Swiwings Idn (Narotama Outlets in Surabaya). is a discounted price of Swiwings products offered and can visit to decide on a purchase.

\section{Literature Review}

\subsection{Brand Image}

The definition of brand image according to Kotler (in Tambunan and Widyanto 2012) is the consumer's perception of the company or its products. According to him the image cannot be implanted in the minds of consumers overnight or spread through just one media.

According to Sagita (2013:4) there are 3 indicators of brand image, namely:

1. Corporate Image, which is a collection of associations that consumers perceive of the company making goods or services. The image of the maker includes: popularity, credibility, the company's network, as well as the users themselves or their users.

2. User image, which is a collection of associations that consumers perceive of users who use goods or services that include the user itself, and their social status.

3. Product image, a collection of associations that consumers perceive of an item or service that includes the attributes of the product, benefits for consumers, and guarantees.

\subsection{Social Media Marketing}

According to Kaplan and Haenlein (2010), social media is defined as a group of internet-based applications that are built on the basis of ideology and Web 2.0 technology. Web 2.0 is the basis of social media platforms. Social media itself consists of various different forms, such as social networks, internet forums, weblogs, social blogs, micro blogging, wikis, prodcasts, images, videos, ratings and social bookmarks.

According to DeMers (2014) indicators used to measure social media marketing include:

1) Quality writing;

2) Interesting photos;

3) Frequency of posting activity. Brand awareness (brand image) is the ability of a prospective buyer to recognize, recall a brand as part of a particular product category.

\subsection{Price}

Price is a unit of the amount of money exchanged to get the benefits of a product or service. There are three price indicators (Kotler and Armstrong, 2008), including:

1. Price eligibility, Products purchased from online have reasonable prices according to consumers.

2. Price conformity with product quality, Prices of products purchased from online are in accordance with the quality of goods sold.

3. There are discounts / discounts, Buyers can get discounts / discounts if the buyer purchases a certain amount.

\subsection{Reference Group}

According to Kotler and Keller (2009: 170) "reference groups are all groups that have a direct (face to face) or indirect influence on the person's attitude or behavior. According to Schiffman and Kanuk (2008) measuring reference groups using three indicators, namely: 
1) Information and Experience

2) Credibility

3) Product's prominent properties

\subsection{Buying Decision}

Peter and Olson (2005, p.162) suggested "purchasing decisions are an integration process that combines knowledge to evaluate two or more alternative behaviors and choose one of them". The definition of consumer purchasing decisions according to Kotler and Amrstrong (2008) is to buy the most preferred brand. Indicators of the purchase decision are as follows:

a. The stability of buying

b. Consideration in choosing

c. Suitability of desires and needs attributes (Andini, et al. 2012)

\subsection{Research Framework}

Sample is part of the number and characteristics possessed by the population. If the population is large, researchers may not study everything in the population. The sampling technique in this study uses a random sampling method (non probability sampling) with the determination technique. The sampling technique used is accidental sampling. The object of this research is the Swiwings Narotama Outlet consumers in Surabaya. The population in this study is the consumers of Swiwings Narotama Outlet in Surabaya, amounting to 171 consumers.

Descriptive analysis is a fact finding that uses proper interpretation. In this research study about the problems that exist in the community environment as well as the procedures used in the community in certain situations. Descriptive research is a type of method that describes an object and subject being studied without engineering. The type of data in this study is primary data, data obtained directly from researchers who come from the object of the researcher. In this study the object is the respondent, using the questionnaire method (questionnaire).

\section{Result and Discussion}

\subsection{T Test}

Table 1 Result of T-test

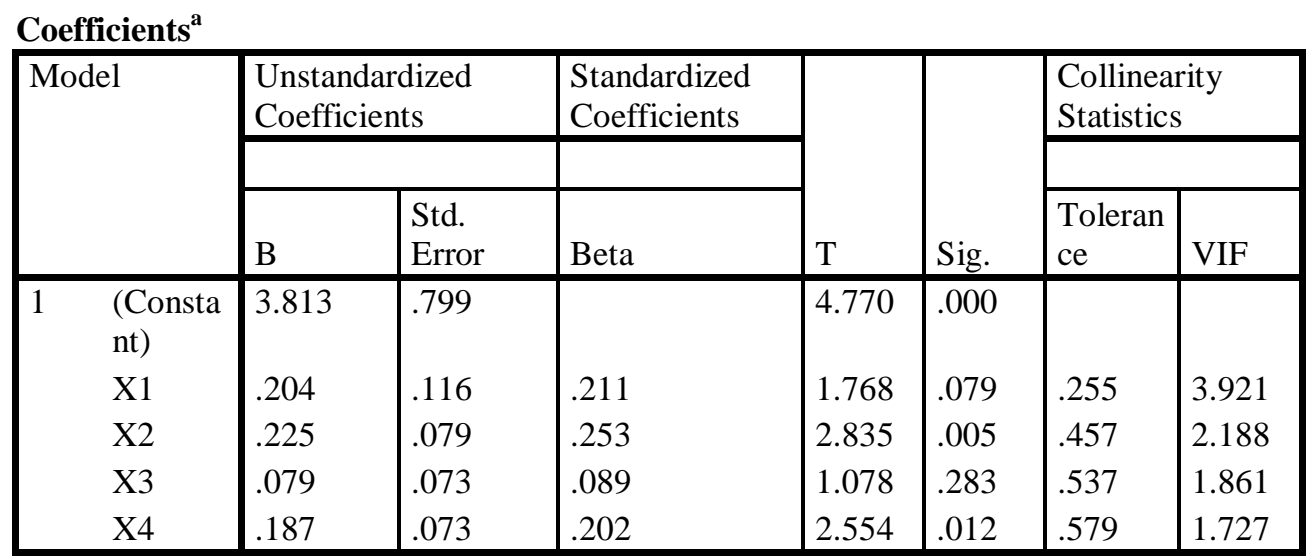

a. Dependent Variable: Y

Based on the above table data on the $\mathrm{T}$ test (partial) above, it is known that significant values in the Brand Image variable (X1) are 1,768> 0.05 thus results of this variable has no significant effect on the Purchase Decision variable (Y). In the variable Social Media Marketing (X2) of $0.005<0.05$ hence results of this variable have a significant effect on the variable Organizational Purchasing Decisions (Y). In the Price variable (X3) of 0.283>0.5, the results of this 
variable do not have a significant effect on the Purchase Decision variable $(\mathrm{Y})$, and the Reference Group variable (X4) of $0.012<0.05$ therefore results of this variable have a significant effect on the variable Purchase Decision (Y). Therefore in the variable Brand Image, Social Media Marketing, Price and Reference Group there are only two variables that significantly influence the variable Purchasing Decision (Y), namely the Social Media Marketing variable (X2) and the Reference Group variable (X4).

1. Brand Image Variable (X1)

The $t$ value of the Brand Image variable (X1) obtained a significance value of $1.768>0.05$. This shows that the Brand Image variable (X1) does not have a significant partial effect on the Purchase Decision variable (Y).

2. SociaL Media Marketing Variable (X2)

The $t$ value of the Social Media Marketing (X2) variable obtained a significance value of $0.005<0.05$. This shows that the variable Social Media Marketing (X2) which has a partially significant effect on the variable Purchasing Decision (Y).

3. Price Variable (X3)

The value of $t$ calculated Compensation variable (X3) obtained a significance value of $0.283>0.05$. This shows that the Price variable (X3) where this variable does not have a significant partial effect on the Purchase Decision variable (Y).

4. Reference Group Variables (X4)

The t value of the Reference Group variable (X4) obtained a significance value of 0.012>0.05. This shows that the Reference Group variable (X4) where this variable has a partially significant effect on the Purchase Decision variable $(\mathrm{Y})$.

Table 2. Result of F test

ANOVA
\begin{tabular}{|ll|l|l|l|l|l|}
\hline Model & & Sum of Squares & Df & Mean Square & F & Sig. \\
\hline 1 & Regression & 227.996 & 4 & 56.999 & 27.381 & $.000^{\mathrm{a}}$ \\
& Residual & 345.560 & 166 & 2.082 & & \\
& Total & 573.556 & 170 & & & \\
\hline
\end{tabular}

a. Predictors: (Constant), X4, X3, X2, X1

b. Dependent Variable: Y

1. Based on the spss output above the significance value of $0,000<0.05$ means simultaneous Brand Image, Social Media Marketing, Price, and Reference Group on Purchasing Decisions.

2. Comparing the calculated $\mathrm{F}$ number with the $\mathrm{F}$ formula table:

$d f_{1}=k-1$

$d f_{2}=n-k$

where $\mathrm{k}=$ number of variables (free and bound), $\mathrm{n}=$ number of observations $/$ samples

$d f_{1}=5-1=4$

$d f_{2}=171-5=166$ 
Monica, et.al | Quantitative Economics and Management Studies (QEMS), 2020, 1(3): 230-236

From these results with a significance level of $5 \%$, the $\mathrm{F}$ value of the table is 2.43 .

from the above spss output above the calculated $\mathrm{F}$ value 27.381> from the $\mathrm{F}$ table 2.43, it means Brand Image (X1), Social Media Marketing (X2), Price (X3) and Reference Group (X4) Purchases.

\section{Conclusion}

The results of data processing showed that there was a significant influence between social media marketing variables and reference groups on purchasing decisions at the Swiwings Narotama Outlet in Surabaya. Consumers agreed that the suitability of promotion through social media marketing such as Instagram and this reference group was able to encourage them to decide on purchases of products. It was also found that the variable brand image and price did not significantly influence purchasing decisions, this shows that the brand image and price of swiwings were not the main consideration for cost to buy swiwing product.

For further researchers can expand the object of research because this research is only reviewed from the perspective of students and the needs for re-research with appropriate variables. The company must work hard by increasing promotion through social media such as Instagram and reference groups. The company should pay more attention to the price of Swiwings Narotama Outlet products. Companies should set a price for each product item or set a pricing method for buying and selling transactions with certain consumers, and companies also increase promotions such as giving discounts for each item or package and every certain day. With the quality of products from Swiwings such as the example of chicken wings that have been cold and not reheated, and the taste of the sauce must be consistent should not change flavors so that consumers can get to know more about the taste image of the Swiwings Narotama Outlet product in Surabaya.

\section{References}

Alireza Mohammadpour, Taher Roshandel Arbatani, Tahmoures Hassan Gholipour, F. F. \& S. H. (2014) "A Survey of the Effects of Social Media Marketing on Online Shopping of Customers by Mediating Variables", Journal of. doi: http://dx.doi.org/10.4236/jssm.2014.75034.

Alvionita, V. (2017) 'The Effect of Word of Mouth, Brand Image and Price on Purchasing Decisions of Chatime, Prijati Indonesian College of Economics (STIESIA) Surabaya ', Journal of Management Science and Research, Vol. 6.

Amron, A. (2018) "Effects Of Product Quality, Price, And Brand Image On The Buying Decision Of City Car Products", Archives of Business Research Faculty of Economics and Business, Dian Nuswantoro University, Semarang, Indonesia, Vol. 6.

Baruna Hadi Brata, S. H. \& H. A. (2017) 'The Influence of Quality Products, Price, Promotion, and Location to Product Purchase Decision on Nitchi At PT. Jaya Swarasa Agung in Central Jakarta ', Saudi Journal of Business and Management Studies, Vol. 2. doi: 10.21276 / sjbms.

Budi D. Soebakir, B. L. \& F. R. (2018) "Influence of Brand, Price and Service Quality on Customers' Decisions to Buy at Gudang Imaji Manado Coffee Shop", EMBA Journal, Vol.6, p. Thing. 3843 - 3852.

Budiatmo, M. K. \& A. (2018) 'The Effect of Social Media Marketing, Brand Awareness on Purchasing Decisions With Purchase Interest as Intervening Variables in J.Co Donuts \& Coffee Semarang ', Journal of Business Administration, Vol. 7.

DH, LM \& AF (2018) 'The Influence of Social Media Marketing on Purchasing Decisions (Online Survey on Bachelor of Business Administration 2014/2014 Faculty of Administrative Sciences Universitas Brawijaya Who Purchases Starbucks Using LINE)', Journal of Business Administration (JAB) Faculty Administrative Sciences Universitas Brawijaya Malang, VOL. 58.

Erfika Rahmi Muharromah, Dede R. Oktini, SE., MP \& Nina Maharan, SE., MS (2017) 'The Effect of Location and Price on Consumer Purchasing Decisions (Study at the Lexa Chicken Restaurant in Rancaekek)', Management Study Program, faculty Economics and Business, Bandung Islamic University. Proceedings of Management. Wave Management 2 academic years. 
Evita, N. (2017) 'The Influence of Brand Image on Purchasing Decisions in (Case Study of Bakso Boedjangan Cabfang Burangrang Bandung in 2017) ', e-Proceeding of Applied Science, Vol. 3

Fadilah, (2019) "Influence of Reference Groups and Pricing on Consumer Purchasing Decisions in KFC Metropolitan City Pekanbaru", Business Administration Study Program - Department of Administrative Sciences, Faculty of Social and Political Sciences, University of Riau.

Hakim, M. L. "The Effect of Price, Brand Image, Product Quality and Promotion on Iphone Purchasing Decisions in Semarang City", Management Study Program - S1, Faculty of Economics and Business, Dian Nuswantoro University Semarang.

Haryanto, A.T. 2019. Pengguna Internet Indonesia Didominasi Milenial. Retrieved from: https://inet.detik.com/telecommunication/d-4551389/pengguna-internet-indonesia-didominasi-milenial.

Kurniawan, Y. D. (2017) Effect of Price Perception, Product Quality and Brand Image on Purchasing Decisions. Sanata Dharma University. Available at: https://repository.usd.ac.id/13953/2/132214098_full.pdf.

Khairani (2018) "The Effect of Brand and Food Safety on the Purchase Decision of Samyang Noodles Product to the Student of the Faculty of Economics and Business of the University of North Sumatra Medan", International Journal on Language, Research and Education Studies, Vol. 2. doi: DOI: 10.30575 / 2017 / IJLRES2018050810.

Masreviastuti, A. I. \& (2019) 'Effect of Store Atmosphere and Reference Groups on Purchasing Decisions at Kediri Workshop Cafe, Journal of Business Administration Business Application, Malang State Polytechnic, Vol. 5

Nasution, H. F. (2018) 'Effect of Ease and Price on Online Clothing Product Purchase Decisions (Case Study of Students Shopping Online at FEBI IAIN Padangsidimpuan) ', Journal of Islamic Business Management and Business, 4, p. Thing. 26-39.

Pratnyawan, A. 2019. Pengguna Instagram dan Facebook Indonesia Terbesar ke-4 di Dunia. Retrieved by https://www.suara.com/tekno/2019/06/19/133252/pengguna-instagram-dan-facebook-indonesia-terbesar-ke-4di-dunia.

Priskyla Wenda Rumondor, A. L. T. \& I. W. J. O. (2017) 'Effect of Product Quality, Price and Word of Mouth on Purchasing Decisions at Coffee Houses and Toronata Noodles in Kaawangkoan, EMBA Journal of Economics and Business, Department of Management, Sam Ratulangi University, Manado, Vol. 5

Riyadi, AFW \& ESH (2017) 'The Influence of Lifestyle, Prestige and Reference Groups on Purchasing Decisions (Study on Consumer Taiwan Tea House Semarang)', National Seminar on Management \& Business Research "Development of E-Business Concepts and Research in Indonesia. Faculty of Economics and Business, Satya Wacana Christian University.

Sugiyono. (2018). Metode Penelitian Kuantitatif Kualitatif dan R\&D. Bandung: Alfabeta

Swiwings. n.d. Retrieved by https://instagram.com/swiwings.idn?igshid=13dj5smihcmk6

Tumewu, M. T. \& F. (2014) 'Analyzing The Influence Of Price And Product Quality On Buying Decision Honda Matic Motorcyles In Manado ', EMBA Journal of Economics and Business International Business Administration (IBA) University of Sam Ratulangi Program Manado, Vol. 2

Utami, A. S. \& D. A. (2016) 'The Effect of Product Quality, Brand Image, and Service Quality on Purchasing Decisions of Dadone Products in Jakarta ', Faculty of Economics and Business, Budi Luhur University Jakarta, Vol. 5

Zahra, G. F. "Influence of Healthy Lifestyle, Prices, and Reference Groups on Purchasing Decisions on Anlene Milk in Kebumen", Department of Management, Faculty of Economics, Muhammadiyah University, Purworejo.

Zuhroh, B. A. P. \& S. (2016) 'The Effect of Promotion on Social Media and Word of Mouth on Purchasing Decisions (Case Study at Bontacos Store, Jombang) ', Communication, Vol. X. 